\title{
УДК: 378.011.3-051
}

\section{SELF-PRESENTATION AS A FORMATION CRITERION FOR THE PROFESSIONALISM OF A FUTURE TEACHER САМОПРЕЗЕНТАЦІЯ ЯК КРИТЕРІЙ ФОРМУВАННЯ ПРОФЕСІОНАЛІЗМУ МАЙБУТНЬОГО ПЕДАГОГА}

Radchenko M. R. / Радченко M. P.

Postgraduate student of the Department of Pedagogy and Management of Education / aспірант кафедри педагогіки та менеджменту освіти http://orcid.org/0000-0001-8897-1343 Volodymyr Vynnychenko Central Ukrainian

State Pedagogical University, Kropyvnytskyi, Shevchenko, 1, 25006 Центральноукраїнський державний педагогічний університет імені Володимира Винниченка, Кропивницький, Шевченка, 1, 25006

\begin{abstract}
Анотація. У статті зроблена спроба розгляду сутності, ролі $i$ значення самопрезентації як важливого критерію формування професіоналізму майбутнього педагога. Активне і иілеспрямоване володіння навиком самопрезентації розглядається як важлива умова успішної професійної діяльності. В роботі вказано, щчо формування вміння самопрезентації майбутнього педагога вимагає від викладачів вищої иколи використання методів портфоліо, інтерактивного навчання, тренінгів, спеціальних технік. Представлено механізми формування у майбутніх педагогів навичок самопрезентації у навчальному прочесі.
\end{abstract}

Ключові слова: самопрезентачія, навички самопрезентації, професіоналізм, майбутній педагог, професійна діяльність.

\section{Вступ.}

Мета сучасної державної політики в галузі педагогічної освіти підвищення якості підготовки молодих фахівців, які повинні з перших днів роботи активно включитися в процес освіти підростаючого покоління. Теоретико-практичні основи найвищого рівня професіоналізму розробляє акмеологія, яка розглядає у взаємозв'язку об'єктивні і суб'єктивні умови, що дозволяють людині досягти найвищої для неї результативності в їі професійній діяльності.

Професіоналізм у будь-якій сфері визначається тим, які мотиви спонукають людину до діяльності, який сенс має в іiі житті конкретна професійна діяльність, яку мету вона ставить, а також які технології застосовує для досягнення поставлених цілей. Якщо майбутній педагог в другий акмеологічний період (навчання у вищому навчальному закладі) сформується як соціально і професійно активна особистість, то він не буде замикатися в колі вузько-педагогічних завдань, а буде рухатися в напрямку постійного саморозвитку, а відтак і розвитку свого професіоналізму.

Процес становлення педагога-професіонала - це досить тривалий i складний процес. Навчання в вищому навчальному закладі забезпечує певний рівень професійної готовності. Чим вищий цей рівень, тим більше підстав для формування професіоналізму майбутнього педагога, хоча професіоналом він може стати лише в процесі професійної практичної діяльності.

Одним із сучасних комунікаційних засобів діяльності, важливою умовою 
формування професіоналізму майбутнього педагога $\epsilon$ здатність до самопрезентації.

Дослідженню самопрезентації присвячена велика кількість робіт. Зокрема, грунтовні дослідження самопрезентації належать таким зарубіжним науковцям як М. Снайдер, І. Джонс, С. Джурард, Д. Майєрс, Т. Піттман, А. Басьо, С. Бріггс, І. Гофман, О. Казанцева, А. Клименко, О. Михайлова та інші.

Як засіб формування «образу Я» самопрезентацію розглянуто в роботах Г. Мід, Ч. Кулі; як засіб самовираження, формування враження висвітлено в працях Р. Баумейстер, А. Стейнхілбер; як саморефлексію, самоконтроль дослідив М. Снайдер; як управління сприйняттям через залучення уваги представлено Г. В. Бороздіною.

Значний внесок в розробку питання самопрезентації, належить педагогам пострадянських країн, серед них О. Белінська, О. Булатова, Т. Астафурова, О. Гойхман, В. Загвязінський, О. Ерліх, А. Коджаспіров, Г. Коджаспірова, Л. Мардахаєв, А. Мудрик, А. Панфілова, В. Сиратов, Р. Буамейстер, А. Стейнхілбер, А. Бороздіна, Ю. Жуков та інші.

Аналіз літературних джерел свідчить, що поза увагою науковців залишилися актуальні питання аналізу сутності самопрезентації як суттєвої умови формування професіоналізму майбутнього педагога.

Мета статті: визначити сутність самопрезентації як умови формування професіоналізму майбутнього педагога, проаналізувати механізми формування само презентації.

\section{Основний текст.}

Поняття «самопрезентація» походить від латинського слова, що в перекладі означає «самоподача», тобто представлення себе іншим людям. В англійському тлумачному словнику воно буквально означає управління враженням про себе у інших людей за допомогою чисельних стратегій поведінки, які полягають у пред'явленні свого зовнішнього образу іншим людям. В американській традиції самопрезентація розглядається як форма соціальної поведінки, демонстративно підкреслена суб’єктом в процесі міжособистісного спілкування.

За визначенням І. Гофмана, самопрезентація - це засіб організації власної поведінки людиною, яка не усвідомлює цей процес і пасивна у виборі засобів $[8,46]$. В посібнику А. А. Клименко смаопрезентація розглядається як вміння презентувати себе, продемонструвати і підкреслити свої кращі якості, важливі в конкретній ситуації $[6,20]$. Відповідно, майбутньому фахівцеві необхідно чітко розуміти, які саме знання та вміння, риси характеру, особливості поведінки будуть доцільні і очікувані в конкретний момент.

В соціолого-педагогічному словнику за редакцією В. В. Радула, самопрезентацію (лат. подання) розглядають як акт самовираження, спрямований на те, щоб створити добре враження, узгодження з ідеалами інших видатних людей [9, 129].

Найбільш повно визначення самопрезентації дано Ж. Тедеші і М. Ріессом, де самопрезентація характеризується як навмисна й усвідомлювана поведінка, спрямована на створення певного враження про себе у оточуючих. До 
споріднених із самопрезентацією віднјсять поняття «самоподача», «самопред'явлення», «управління враженням» [7, 38].

У роботах Є. В. Михайлова та Л. М. Семенова відзначається, що самовияв, (самопрезентація) виступає як соціально-психологічний феномен, що пронизує всі сторони міжособистісної взаємодії, він пов'язаний з різними потребами й життєвими цілями людей. Самопрезентація дає особистості, майбутньому професіоналу додаткову можливість представити себе, заявити про свої досягнення, наміри, уміння i навички. Однією 3 форм професійної самопрезентації в умовах підготовки до педагогічної діяльності $\epsilon$ публічні виступи перед аудиторією, відкриті лекції, проведення майстер-класів тощо.

Як резюмує в своєму дослідженні Казанцева О. В. [4, 2], самопрезентація має тісний взаємозв'язок 3 окремими психологічними механізмами й особистісними та професійними вміннями. Володіння навичками самопрезентації сприяє легшому входженню в контакти 3 іншими. Майбутній педагог зі сформованим вмінням самопрезентуання завжди орієнтований на отримання повноцінного зворотного зв'язку від співрозмовника або аудиторії, більш відкрито проявляє свої почуття i емоції. Самопрезентація відкриває унікальну можливість змінити внутрішню глибинну сутність типів педагогічної взаємодії, зробити діалог між педагогом і учнем / студентом більш доступним, необхідним i ціннісним, сформувати нові механізми i рівні розуміння в міжособистісній взаємодії.

Уміння демонструвати себе, свої емоції, висловлювати щиру емпатію i зацікавленість у партнері по спілкуванню - все це повинно цілеспрямовано формуватися в ході практики i навчальної взаємодії. Майбутні педагоги повинні навчитися відкрито оголошувати про свої цілі і способи їх досягнення, що дозволить відмовитися від використання жорстких маніпулятивних засобів, прагнути знайти площину перетину в умовах взаємодії «педагог-учень / студент». Орієнтація на формування самопрезентації також вимагає від майбутнього педагога вміння отримувати зворотний зв'язок та здатності до саморефлексування.

Дослідження самопрезентації відбувається в одному ряду з категоріями іміджу, репутації, соціальної взаємодії та комунікації.

У своєму дослідженні I. I. Киричок та А. I. Рожнова зауважують, що самопрезентація корелює 3 поняттями «маніпуляція», «іміджування», «імідж». Самопрезентація - вербальна та невербальна демонстрація власної особистості в системі зовнішніх комунікації, процес та результат засвоєння та відтворення соціального досвіду, вміння подавати себе в різних ситуаціях, індивідуальний стиль спілкування, здатність створити неповторний образ. Вони наголошують, що феномен самопрезентації багатоаспектний, представляє собою механізм формування позитивного ставлення до себе з боку оточуючих людей та маніпуляції на основі досягнутого ефекту тяжіння; як засіб проникнення в глибину власної самосвідомості та переоцінки поведінки та стосунки 3 навколишнім світом; як чинник досягнення когнітивного балансу [5, 373].

Ефективна самопрезентація пов'язана з усвідомленням людиною власних сильних і слабких сторін, умінням проявити та продемонструвати переваги, а 
також зі знанням способів подолання або компенсації недоліків. самопрезентація значною мірою залежить від здібності і схильності особистості до рефлексії, самоаналізу, від адекватного уявлення людини про вимоги до неї 3 позиції діяльності.

Як зазначає А. А. Клименко, у процесі професійної педагогічної освіти повинні вирішуватися три взаємопов'язаних завдання:

1. забезпечення відповідності випускників вимогам професії за допомогою підготовки кваліфікованих, компетентних фахівців, здатних ефективно виконувати професійні функції;

2. забезпечення здатності випускників відповідати вимогам соціуму, ринку праці, робочого місця та роботодавця шляхом формування у студентів системи знань і навичок пошуку і відбору інформації про відповідні вимоги, умінь визначати свою відповідність цим вимогам, знаходити способи подолання виявлених недоліків тощо;

3. формування у майбутніх педагогів здібностей до ефективної самопрезентації $[6,4]$.

Перші два завдання відображають зміст самопрезентації («що презентувати»), проте, в умовах навчання у ВНЗ, якісно і системно вирішується тільки перша задача.

Здатність до самопрезентації необхідно розглядати в числі значущих особистісно-професійних якостей фахівців, що обумовлюють їх конкурентоспроможність на ринку праці, тому цей феномен повинен бути належним чином сформований в майбутніх педагогів ще в період навчання у BH3.

Уявлення людини про себе $є$ одним 3 факторів, що визначає зміст самопрезентації, а саме, того враження, яке суб'єкт прагне сформувати у оточуючих, i зміст образу, який він транслює 3 метою створення цього враження.

Г. Бороздіна пропонує класифікацію технік самопрезентації, припускаючи, що саме цей феномен запускає механізми соціального сприйняття та, на нашу думку відіграє досить важливу роль у формуванні професіоналізму майбутнього педагога [2]. Ю. Жуков формулює правила комунікації та самоподання, які виконують дві основні функції: створення в оточуючих певного враження та регуляцію власної поведінки в критичних ситуаціях [3, 32].

Самопрезентація, або іміджуванння, може частково використовувати методи маніпуляції у процесі формування іміджу, але цей вплив не може застосовуватися всупереч бажанням аудиторії іміджування, бо таке втручання суперечить механізмам створення необхідного позитивного образу [5, 371].

Слід наголосити, що професійна успішність майбутнього педагога обумовлена не тільки його професіоналізмом, а й відносинами, які складуться у нього 3 іншими суб’єктами професійної взаємодії. Так, для споживачів професійних послуг важливим є небайдуже, зацікавлене ставлення фахівця до їх інтересів, потреб і проблем, комунікабельність тощо [6, 21]. Очевидно, для 
успішної трудової діяльності майбутньому педагогу важливо не тільки володіти такими значущими характеристиками як ініціативність, креативність, професійна відповідальність, готовності до саморозвитку, комунікабельність тощо, але й вміти їх демонструвати, проявляти згідно ситуацій професійної діяльності, тобто вміти самопрезентуватися.

До основних якостей, умінь i навичок, які забезпечують ефективну самопрезентацію майбутнього педагога відносяться наступні:

- навички конструктивної рольової поведінки;

- володіння ефективним стилем поведінки і спілкування;

- емоційна позитивність і стресостійкість;

- вміння конструктивно (змістовно, лаконічно) розповісти про себе;

- позитивні життєві установки (впевненість в собі, індивідуальність, дотримання етики ділового спілкування, переконливість, зацікавленість, обізнаність, адекватний зовнішній вид, організованість тощо).

До важливих для самопрезентації характеристик особистості також відносяться: креативність, доброзичливість, комунікабельність, емпатію і рефлексію, самоконтроль і самовладання, духовність і моральність, оптимізм, волю, терпимість тощо.

Наведені особистісні якості представляють собою фактори ефективної самопрезентації, та, одночасно, частина змісту інформації про зовнішні умови самопрезентації.

Формування само презентаційних навичок майбутнього педагога вимагає від викладачів вищої школи використання методів портфоліо та інтерактивного навчання: групова дискусія, брейнстормінг, кейс-метод, рефлексивно-рольова, ділова й проблемно-діяльнісна гра, доцільним також буде викладання спецкурсу «Формування навичок самопрезентації», проведення тренінгів 3 використанням вправ «Публічний виступ», «Сонечко» тощо, використання різних технік, підготовка презентацій образу [5, 372].

Аналізуючи техніки самопрезентації, доцільно навести техніки, представлені Р. Чалдіні:

- техніка насолоди відбитої славою («купання в променях чужої слави») використання чужого успіху для самопрезентації;

- техніка нанесення шкоди («шкідництво») - навмисне перебільшення недоліків (ситуації, предмета, іншої людини тощо) для підвищення свого статусу, свого росту в очах оточуючих, що дозволяє управляти враженням інших [1,21].

Формування навичок самопрезентації в умовах навчання ВНЗ доцільно здійснювати із залученням методів активного соціально-психологічного навчання майбутніх педагогів. До них відносяться: групова дискусія, брейнстормінг, методи ігрового моделювання професійної діяльності (ефлексивно-рольова, ділова i проблемно-діяльнісна гра). Активні методи навчання сприятимуть розвитку рівня персональної відповідальності i спрямованості на створення унікального індивідуального професійного образу, в тому числі і засобами самопрезентації. Самопрезентація може виступати як 
оригінальний критерій педагогічної компетентності майбутніх педагогів. У цьому випадку ступінь професіоналізму буде реєструватися на основі ретельної підготовки висунутого образу, умінні його транслювати i через нього відкривати педагогічні ідеї та гуманістичні цінності. Шаблонне (формальне) самопред'явлення професійних умінь і особистісних якостей буде відповідати низькій компетентності, а глибоке особистісно відрефлексоване (на рівні саморозкриття в рамках педагогічної діяльності), буде розглядатися як показник високого професіоналізму та професійної компетентності.

\section{Висновки.}

Самопрезентація в педагогічній площині виступає як критерій професіоналізму та критерій педагогічної компетентності майбутніх педагогів. Формувати та розвивати навички самопрезентації у майбутніх педагогів можна за допомогою використання інтерактивних методів навчання, методу портфоліо, проведення тренінгів та практикумів із психокорекції, викладання спецкурсів тощо.

В роботі ми дослідили таку важливу умову формування професіоналізму майбутнього педагога як самопрезентація. Ми проаналізували кілька підходів до трактування поняття, визначили, що дослідження самопрезентації відбувається в одному ряду 3 категоріями іміджу, репутації, соціальної взаємодії та комунікації.

Ми навели кілька класифікацій технік само презентації, зокрема класифікацію Р. Чалдіні. Ми дійшли висновку, що формування навичок самопрезентації як умови формування професіоналізму майбутнього педагога в умовах навчання ВНЗ доцільно здійснювати із залученням методів активного соціально-психологічного навчання майбутніх педагогів та навели основні 3 них.

\section{Список використаних джерел}

1. Болотова А. К. Психология коммуникаций [Текст]: монографія / А. К. Болотова, Ю. М. Жуков; Нац. исслед. ун-т «Высшая школа экономики». М.: Изд. дом Высшей школы экономики, 2015. - 495 с.

2. Бороздина Г. В. Психология и этика делового общения: учебник для бакалавров / Г. В. Бороздина, Н. А. Кормнова; под общ. ред. Г. В. Бороздиной. М.: Издательство Юрайт, 2012. - 463 с.

3. Жуков Ю. М. Эффективность делового общения / Ю. М. Жуков. - М.: Знание, 1990. - 64 с.

4. Казанцева E. В. Формирование навыков самопрезентации как профессионально необходимых качеств будущих педагогов-психологов // Концепт. - 2013. - Спецвыпуск № 5. - С. 2.

5. Киричок I. I. Самопрезентація майбутніх керівників загальноосвітніх навчальних закладів як психолого-педагогічна проблема / I. I. Киричок, А. І. Рожнова. - Науковий журнал «Молодий вчений». - Серія «Педагогічні науки». - № 5 (45) травень, 2017. - С. 371-373.

6. Клименко А. А. Самопрезентационная компетентность: содержание и основы формирования: учеб. пособие / А. А. Клименко, С. А. Хазова, 
С. А. Карасева. - Краснодар: КубГАУ, 2018. - 67 с.

7. Коммуникативные практики в современном обществе: сб. науч. ст. / Под ред. В. В. Васильковой, И. Д. Демидовой. - СПб.: Скифия-принт, 2008. - 344 с.

8. Михайлова Е. В. Обучение самопрезентации: [учеб. пособ.] / Е. В. Михайлова. - М.: ГУ ВШЭ, 2006. - 167 с. - С. 46-52.

9. Соціолого-педагогічний словник / За загальною ред. В. В. Радула, вид. 2ге. - Харків: Мачулін, 2015. - С. 129.

Abstract. The article attempts to consider the essence, role and significance of selfpresentation as an important criterion for the formation of professionalism of the future teacher. Active and purposeful mastery of the skill of self-presentation is considered as an important condition for successful professional activity. The paper indicates that the formation of the ability of self-presentation of the future teacher requires high school teachers to use the methods of portfolio, interactive learning, training, special techniques. The mechanisms of formation of future teachers' skills of self-presentation in the educational process are presented.

Keywords: self-presentation, self-presentation skills, professionalism, future teacher, professional activity.

Науковий керівник: д.п.н., проф. Радул В. В.

(C) Радченко М. Р. 